\title{
Practices of looking, transformations in cheering: alliances and rivalries in upper xinguan wrestiling
}

\section{Carlos Eduardo Costa}

\section{(2) OpenEdition \\ 1 Journals}

Electronic version

URL: https://journals.openedition.org/aa/8343

DOI: $10.4000 /$ aa. 8343

ISSN: 2357-738X

\section{Publisher}

Programa de Pós-Graduação em Antropologia Social (UnB)

\section{Printed version}

Number of pages: 254-270

ISSN: 0102-4302

Electronic reference

Carlos Eduardo Costa, "Practices of looking, transformations in cheering: alliances and rivalries in upper xinguan wrestiling", Anuário Antropológico [Online], v.46 n.2 | 2021, Online since 30 May 2021, connection on 01 June 2021. URL: http://journals.openedition.org/aa/8343 ; DOI: https://doi.org/ 10.4000/aa.8343

\section{(9) $\odot \Theta \Theta$}

Anuário Antropológico is licensed under a Creative Commons Atribuição-Uso Não-Comercial-Proibição de realização de Obras Derivadas 4.0 International. 


\title{
anuário antropológico \\ v. $46 \cdot \mathrm{n}^{\circ} 2 \cdot$ maio-agosto $\cdot 2 \odot 21.2$
}

\section{Practices of looking, transformations in cheering: alliances and rivalries in Upper Xinguan wrestling ${ }^{1}$}

DOI: https://doi.org/10.4000/aa.8339

\author{
Carlos Eduardo Costa \\ Universidade Federal de São Carlos, Programa de Pós-Graduação em Antropologia \\ Social, São Carlos, SP, Brasil \\ PhD at the Graduate Programme in Social Anthropology at UFSCar, founding member of the Laboratory \\ for the Study of Ludic Activity and Sociability (Laboratório de Estudos das Práticas Lúdicas e Sociabilidade, \\ LELUS/UFSCar), and collaborator at the Ludopédio website.
}

Kindene wrestling is one of the most frequently recorded practices in the Upper Xingu, from the pioneering expeditions of the 19th century to researchers who worked toward the demarcation of the Indigenous Land in the mid-20th century. Even with the recent demographic increase of peoples and the diversification of ethnographic themes addressed, the kindene remains the subject of succinct, if acute, descriptions. Despite this epiphenomenal character, in the midst all the ritual sumptuousness in which it is primarily disputed wrestling mobilizes political strife involving the chieftaincy; historical rivalries that span generations; transformations that consolidate regional systems; emotions and performances between wrestlers and fans. The dynamics of ritual organization, especially of the egitsü, a post-funeral ceremony in honour of chiefs, shuffles inter-ethnic relations. Such configurations promote alliances and oppositions that affect the formation of teams, and, consequently rearranges the fans at each event. This article gives greater visibility to the relations between playing and cheering, mediated by the faculty of looking, in the celebrations of victories, indicating the transformations unleashed in the relational universe of the peoples of the region. Fundamental positions for ritual combats, the nginiko ("onlookers"), bring to light new angles to deal with the complexity of relationships in the context of the so-called pax xinguana. 


\section{Presentation}

Kindene $e^{2}$ wrestling is a sportive practice of the peoples of the Upper Xingu. It is constituted by a set of traditional, mythological, and ritual knowledge which gives shape and content to a primordial means for relating across ethnic divides, clearly highlighting aspects of the so-called pax xinguana, the main characteristic attributed to the peoples of the region. The pax xinguana is notable for the "taming" or "Xinguanization" of the multifaceted peoples who came to compose this regional complex (Menezes Bastos, 1984, 1995). It is likewise notable for the expansion of typically calm and generous behaviour, ritual formality, and a diet that avoids game meat and any hint of cannibalism. Ritual wrestling is a decisive expression of these processes, which are often described as a "becoming human"3 (Basso, 1973, 1995; Coelho de Souza, 2001).

A detailed understanding of wrestling requires the description of a variety of interlinked segments that can be decomposed only for analytical purposes: mythological teachings, which distinguish those people who wrestle from those who do battle (Agostinho, 1974a; Galvão, 1979; Fausto, 1999); ritual language as the preferential anti-warfare idiom in this multi-ethnic and multi-linguistic complex, and the corresponding expansion of the system of exchanges (Gregor, 1990; Menezes Bastos, 2001); native exegeses of the people who come to make up this regional system (Menezes Bastos, 1989; Basso, 1993); and "corporality", the "focal symbolic idiom" in the study of Amerindian peoples (Viveiros de Castro 1977, 1979; Seeger et al., 1979).

"Corporality" can furthermore shed light on themes that have received less attention in the ethnological literature, such as the disporting of practices which some authors refer to as "Amerindian sportiveness" (Vianna, 2008). As Indigenous wrestling is frequently called a "sport", I seek to understand disporting processes as they link with wider processes of the pacification of social relations. There are historical processes analogous to the Xinguan case, in which a set of matrimonial, commercial, and ceremonial practices all played a decisive role in the pacification of interethnic relations and found in sportive contests a defining feature ${ }^{4}$.

With all its attending splendour, wrestling is carried out only in restricted situations, particularly in ceremonial events. Such occasions engage differing emotional dispositions, despite the dynamics of the matches being more or less similar. In the egitsü, more commonly known as Quarup, the post-mortuary ritual in honour of deceased chiefs, tensions and ambiguities surface, while disputes and rivalries are resolved (or renewed) during the matches (Guerreiro, 2012, 2015; Costa, 2013). In contrast, during the uluki ceremonial exchanges, which are proportionally smaller affairs, with fewer participants, the friendly character of matches tends to be stressed (Novo, 2020). In the tiponhü rite of passage, which commemorates the start of adolescent seclusion for young chiefs (Barcelos Neto, 2005), wrestling matches occur after the ears of the initiates are pierced, as they enter into this phase of bodily fabrication and are presented as members of the chiefly line of succession. Finally, female wrestling matches occur in the iamuriku-
1 I would like to thank the two anonymous reviewers and the editorial team of the Anuário Antropológico, especially Professor Kelly Silva, for their careful comments, critiques and suggestions, all of which have greatly improved the article. I also thank Professor Luiz Costa for translating the article into English.

2 Indigenous words and expressions are written in italics. The fieldwork on which this article is based was carried out among the Kalapalo of Tanguro village, and resulted in a $\mathrm{PhD}$ thesis (Costa, 2013). Following standard methods of ethnographic research in Amazonia, I spent a total of some 14 months in the field, spread out through five separate trips. This strategy allowed me to be present at 8 editions of the egitsü, the culmination of Xinguan wrestling, which is both the conceptual and empirical theme of my research. Kindene is the name of the wrestling practice more usually called huka-huka, a term restricted mainly to the "contact Portuguese" spoken in the region.

Various authors have made note of the similarities in markers of alterity in the region. For the Kalapalo, kuge hekugu ("true people") is a sort of auto-designation, emerging from the otomo, which can be translated as "the people of", denoting kinship closeness and generally related to a specific territory. Kuge ("people") are those with whom interethnic relations can be established, whether through ritual, commercial exchanges, or matrimonial alliances. It designates those who share a way of life with characteristics such as a fish-based diet, pacifism, circular villages, affinal avoidance. Ngikogo are "different others", Indigenous populations with sporadic contact, "ugly, angry" people, an image of a distant and dangerous alterity. Finally, the kagaiha are the "whites". Knowing how to wrestle is a pre-requisite for being a "person". 
$m a$, related to the sacred flutes and marked by the heightened presence of women (Mello, 2005).

However, it is not only during rituals that the matches occur, which is part of the reason why they serve as a model for interethnic relations. One does not wrestle with coresidents, except in training sessions which seek to hone skills, or else playfully, as part of the informality and camaraderie that is typical of daily events, such as bathing at dusk in the river.

The true wrestling match (kindene hekugu) is necessarily against the other, which is why it is relatively common for a newly arrived visitor to head to the central patio, where he faces off with all of the local wrestlers. He is looked on with disdain if he is unable to withstand the matches. Wrestling is also present when ritual alliances are established. The peoples who come together for an event confront each other as soon as the allies arrive in the host village. These matches are followed by the presentation of the atanga flutes, the instruments of the champion wrestlers, which seal the ritual alliance. One does not wrestle against those with whom one plays the flute, at least not in that egitsü, in honour of those chiefs to whom they are related as kin.

It is evident that wrestling is a constant presence, a cardinal means of dealing with alterity, whether in the diversity of the regional ceremonial system, in informal visits to foreign villages, or even in the consolidation of alliances. For methodological reasons, my focus will thus be on the egitsü, which is the culmination not only of wrestling, but, it might be said, of the very universe of Upper Xinguan peoples itself. It is a unique occasion which brings together in the same space and time the nine people that make up this regional complex. It is through the description and analysis of the egitsü that I will investigate the theoretical domains outlined above, from mythology to ritual, from interethnic relationships to historical developments, from warfare to pacification. In brief, my focus is a sportified political regime for dealing with alterity which connects wrestlers and fans in performances of skill and opposition.

I will briefly contextualize the region and its main ritual, the egitsï, the apex of the kindene disputes. I inscribe these practices within regimes of alliance and rivalries, instated by kinship between the chiefs and those who are being honoured, in which looking and being seen are structuring features. Sorcery, too, is a fundamental part of these relations. Ritual organization composes varied wrestling teams at each event: hosts plus allies versus guests, highlighting the relationship between chieftaincy and the public exhibition of performances.

I will then shift to transformations in the relations between the peoples who make up this ritual complex. Starting from descriptions provided by an older literature, I will show that while past skirmishes associated wrestlers and fans, they occurred in a climate of permanent instability, straddling a tenuous line between the enemy and/or adversary at a time when warfare and ritual coexisted. This literature thus emphasizes the silence of the spectators and the emotional control of those involved as a means to prevent animosities from coming to the fore. After the legal demarcation of the Xingu was completed, and despite the
4 For Elias (1992), who is concerned with the many facets of the civilizing process in the West, sportification is concerned with transformation and change; it is not a thing, but a process which changes some thing: "it clearly shows how sport is a strategic phenomenon for a broad historical understanding which he calls the civilizing process" (Leite Lopes, 1995, p. 141). In tandem, I will show how Upper Xinguan bodily practices are embedded in wider networks of relationships that aim to reduce bellicose conflicts in favour of disputes - all of which occurs in a region characterized by the "idiom of corporality". I propose to focus on kindene as an interethnic relational model, part of the consolidation of the paxxinguana, in consonance with the other (commercial, matrimonial, ceremonial) practices adduced. 
persistence of ambiguities, authors have come to emphasize the abandonment of warfare and its replacement with a model based on exchange, resulting in the so-called pax xinguana.

Finally, I will stress how contemporary matches are meant to elicit the participation of fans, by means of which I will introduce the nginiko ("onlookers"), those who, through sight, mediate between wrestlers and fans, producing and extrapolating the celebrations of the matches. This is the theme of the third section of the article, and the main contribution of this article to the ethnography of the kindene.

By emphasizing sight, I will provide a dual ethnographic perspective: first, stressing the importance accrued to the visibility of the future chiefs during ritual moments through "public exhibition and substitution" (Guerreiro, 2012); second, and at the same time, I draw the readers' attention to those who will be presented as "onlookers", key positions in ritual organization, occupied by the great masters and champions of the past. I hence seek a connection between the sensibility of the gaze and ways of playing and cheering, as put forward in models of the relations of looking/playing/cheering (Toledo, 2019).

\section{Chieftaincy/Sorcery, Alliances/Rivalry: wrestling in the egitsü}

The Upper Xingu is usually described through the relations between peoples speaking languages from three families: Carib (Kalapalo, Kuikuro, Matipu and Nahukua); Arawak (Wauja, Mehinaku, Yawalapiti); and Tupi (Kamayurá, Aweti). When the current limits of the Xingu Indigenous Park ${ }^{5}$ became legally consolidated, these people each inhabited one village. Today, as their numbers have swelled, each of these peoples occupies many villages, themselves composed of families of different peoples, a "mixture" and "colouring" of the region that is summed up in the idea of tetsualü (Mehinaku, 2010).

This increase in the number of villages draws attention to a crucial theme: sorcery as a driving force of politics, both internally, in establishing factions, and regionally. This double movement of territorial fragmentation and association was studied by Guerreiro (2012) through the constitution of the Kalapalo chieftaincy and mortuary ritual. The chief is like a "superfather" to his people, attesting to consanguinity as a marker of local sociability, his "vegetal-becoming"; for other peoples, in contrast, the chief expresses a "Jaguar-function" through his ritual speeches, projecting affinity and predation as regional sociality (cf. Fausto, 2017). He is the "owner of the dead" for those within, and the "owner of death" for those without. Synchronically, the expansion of this process results in the separation of villages and regional conglomerates; diachronically, it results in the separation of peoples.

For Barcelos Neto, the relationship between chieftaincy and sorcery triggers other forms of dealing with alterity, which can engender either a decline in the chief's prestige, leading to the dispersal of his people and a recurring territorial fragmentation, or the amplification of his influence, his scope of action,
5 For more information on Decree $n^{\circ} 50.455$ of the 14 th of April 1961, signed into law by president Jânio Quadros, see Lea (1997, p. 73) and Menezes (2000, p. 299). Currently, the land is called Terra Indígena do Xingu (Xingu Indigenous Land, TIX). 
increasing the population of his village. This relationship between chieftaincy and sorcery is developed in Wauja rituals, geared towards the confection of masks and the chiefly capacity to gather people to carry out feasts 6 . Sorcery has a dual political effect, eliminating or exiling a chief's adversaries, or turning others against him and compromising his prestige (Barcelos Neto, 2006).

The structural character of the relationship between chieftaincy and sorcery must be stressed. In the absence of warfare, every death is considered to be caused by sorcery, and every dead chief must have an egitsü in his honour (Vanzolini, 2010). This activates a cycle: more dead chiefs, more interethnic rituals, leads to increased possibility of being a victim of sorcery, whether at the local or regional level, both of which are highly interdependent (Franchetto; Heckenberger, 2001).

I mention briefly this contentious theme so as to return to wrestling in the egitsï ${ }^{7}$ The relations between village fragmentation and organizational alliances, itself a reflection of the opposition and association of chieftaincy and sorcery, is the dynamic that drives the preparation of the ritual. The egitsü is a post-funerary rite in honour of dead chiefs, the close kin of which are the "owners of the dead" (c.f. Fausto, 2008 and Guerreiro, 2016 on the category of the "owner") whose task it is to carry out numerous procedures, among which are the invitations. The "owners of the dead", along with the host chiefs, send out two types of invitations: one for allies, whose families are related through kinship with the dead chief being honoured; and another for the guests, who will be wrestling adversaries.

I mention this intricate system of invitations to deal with the matter of alliance, but from a different point of view. This "strategic" character of alliances, discussed by authors such as Cohn and Sztutman (2001), will be developed within this context of social pacification. In doing so, I return to a frequent theme in the region which insists on the transformation of warfare into ritual, articulated as wrestling matches: "the categorical claim, of the Xinguano's and their researches, that the ritual takes the place of war" (Hugh-Jones, 2015, p. 699). To be sure, this idea harks back to the work of Clastres, for whom Indigenous warfare presupposes an alliance on another level:

An alliance, which is not desired as an end in itself, but only as a means: the means to undertake warfare with the lowest risks and costs possible... In brief, the reality of alliance makes possible a total exchange that respects not only goods and services, but also matrimonial relations (Clastres, 1980, p. 36-37).

Briefly stated, it is in the association between these strategic alliances and historic rivalries that the positions occupied in each new ritual are consolidated, directly affecting wrestling matches: the "owners"; the "allies", related to the deceased through kinship; and the "guests", who will be their rivals". The host team and its allies thus face off against each of the invited peoples, with matches occurring separately. In general, hosts ally themselves to one or two peoples, taking part in five or six matches, depending on the number of participating guests.
6 Fausto (2007, p. 30) divided Upper Xinguan rituals into "feasts for spirits and feasts for important peoples". I will render these as, respectively, "feast" and "ritual" (Perrone-Moises 2016).

$7 \quad$ The egitsü occur during the dry season, sometime between July and October. At present they occur with at least a fifteen-day interval between one and another, with three to five rituals being common, depending, of course, on a number of conditions.
8 For a more complete understanding of the organizational positions (owners of the dead, owners of the guests, coordinators, inviters, allies, guests) and the system of invitations, see Guerreiro (2012, p. 49, 419). Here I will focus on these positions as they pertain to the wrestling teams: hosts plus allies versus guests, positions which trade places at each event. 
This means that hosts wrestle in many more matches than their adversaries. A host champion can wrestle up to ten times in a single day, while a guest champion will wrestle two or three times.

Wrestling in the egitsü is the end of a cycle of activities. Here we can only make passing reference to the main events: offering food; gathering and ornamenting the effigies that will be honoured; speeches; songs; flutes; dances; the theft of fire - all stages of the cycle which occur before wrestling. I now focus on the matches themselves 9 .

Typically, on a Sunday morning, hosts and allies gather in the houses of those who are being honoured in the ritual, and in the "flute house" in the centre of the village. The opponents camp in the outskirts of the village, at some distance from each other. The owner of the egitsü summons the wrestlers, and the host wrestlers perform a characteristic dance until they all join together at front of the flute house. The opponents then begin to enter the patio, encircling the hosts with great flair, shouting and stamping their feet.

Right before the matches the configuration is the following: hosts and their allies in the centre, guests in the patio, spaced out in a semicircle. The matches pit hosts against each of the guests in turn. A further organizational division is tied to politics, more specifically to chieftaincy. The "champions" (kindotoko, lit: "owners of wrestling"), also called the "firsts" (hotuko), who are future potential chiefs, are kept separate from those whom we will here call "common wrestlers". This separation seeks to establish visibility, to present the substitutes of the current chiefs, the latter choosing and determining the order of the presentations ${ }^{10}$. Some ten to fifteen matches take place, one at a time, between local champions and opposing champions. These are followed by matches between the common wrestlers, many of which take place simultaneously.

I call a "contest" the set of individual and collective presentations, between the hosts and each of the guest peoples, each of which is preceded by a new summoning and the exhibition of each of the champions to all of them. While I call this set of matches a "contest", I call "combat" the wrestling matches held between two adversaries. The principles are the same: to achieve victory, the wrestler must grab the back of their opponent's leg, hold it from behind, or deliver a blow that tosses the opponent aside. To these ends, they make use of a variety of techniques and tactics (fifteen different blows were identified among the Kalapalo) which consist in grabbing the hands and neck of an opponent and forcing him to lose balance, so as to then deliver the winning blow to the back of his legs or to make him fall ${ }^{11}$.

The difference lies with those who are watching the match: better fighters elicit greater expectations, more effusive emotions, more ecstatic celebrations in victory, and more crippling deceptions in defeat. This explains the importance of the "firsts" and the visibility of the association between participating as a competitor or a fan. The best wrestlers, produced in chiefly families, are being presented as "substitutes" of current chiefs, who coordinate the ritual. They are exhibited even before they perform.
9 Not only have these stages been amply described in studies of the egitsü, they can be visualized in: https://youtu. be/VYuRFI5FJh0 This video of the Awapa Yawalipiti Association synthesizes the main events of the so-call "finale" of the ritual. Accessed on: Mar. 2021.

10 Saturday, on the eve of the contests, the chiefs of the hosts and allies gather in the centre of the village and formally summon the champions. The pre-established order follows technical capacities: the better fighters are called first. Only champions are summoned, and they exit their houses and present themselves in the centre of the village, in a squatting position similar to the one they will assume in the wrestling matches the following day. The order in which wrestlers are summoned, which is negotiated by the chiefs and affords a window on the "strategic" character of alliances, takes a number of contingent aspects into account, such as injuries, fatigue, sorcery.

11 In myth, wrestling takes place during the first egitsü, carried out by Sun and Moon in honour of their mother, and it pits land animals against fish. A series of matches between the champions of each team end in draws, until two fights reveal the winning techniques. The characters involved occur frequently in mythology: Tapir and Frog. Tapir, which is seen to be clumsy and inept, is thrown to the ground by Grasshopper, landing on its behind, which is why today it has a flat bum. Frog, a dubious figure of alterity in local mythology, is a strong and able wrestler, but is defeated by one of the heroes of the narrative, Kangasingi, who wrestles for the Fish team and manages to touch the back of Frog's thigh (Costa, op. cit., p. 301). 


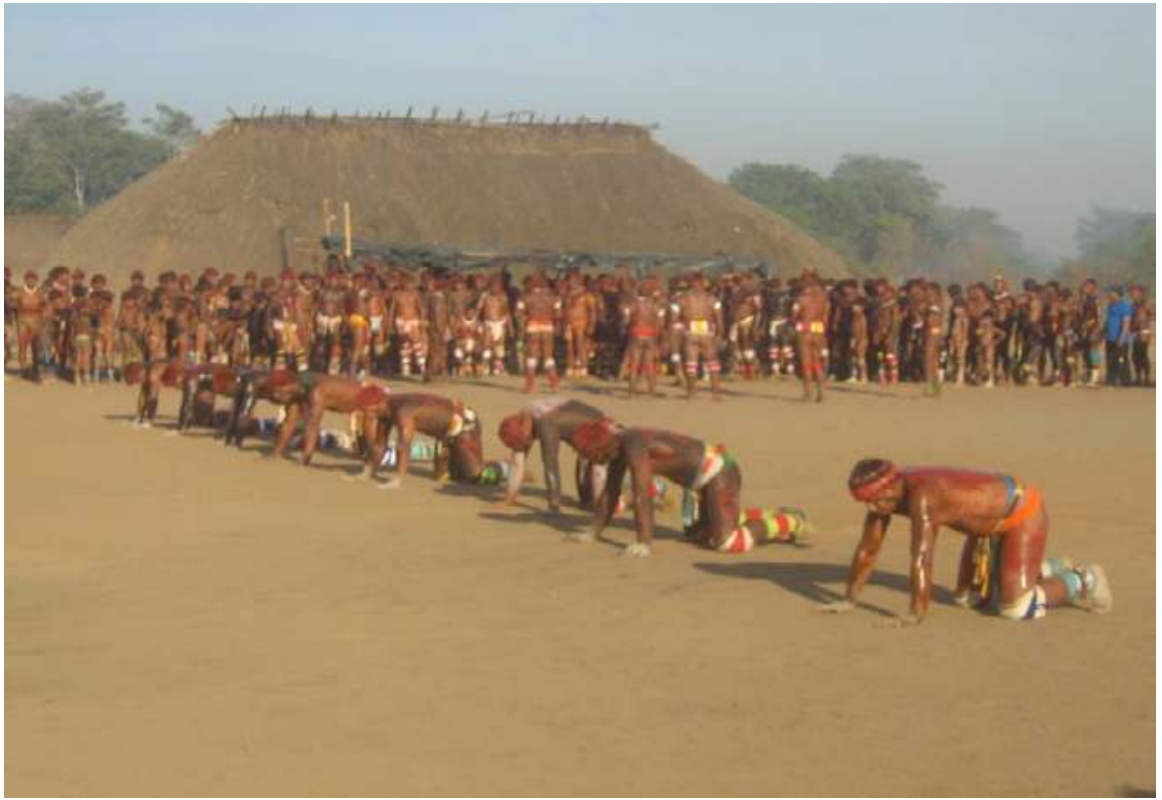

The kindotoko are the products of material and symbolic investments, both by individuals and families, and they are fashioned in a similar manner, mostly through seclusion ${ }^{12}$. Small variations are put to the test during matches, which may account for the high incidence of draws. The opposing wrestlers (tikidinhï) are homologous to each other, which places them in an ambiguous situation. If kinship links the chiefs who jointly organize a ritual to the dead person being honoured, their difference to other chiefs must somehow be instated. The disjunction caused by a victory, particularly one in which the opponent receives a blow which tosses him aside, and which is celebrated effusively by the fans, maintains an instability in the relations.

In this landscape of alliances and rivalries, ambiguities and uncertainties, ritual wrestling will be investigated as a transformation of warfare, one of the characteristics of the pax xinguana. In the well-known, synthetic phrase of a Mehinaku man: "We don't make war; we have festivals for the chiefs to which all of the villages come. We sing, dance, trade, and wrestle" (Gregor, 1990, p. 113).

\section{Pacification/Sportification: transforming enemies into adversaries}

Wrestling has been the object of attention ever since research in the region began, so it is possible to trace some of the changes it has undergone through time. Von den Steinen describes an occasion in which he, "by accident", observed contests between different peoples during his travels - that is, they were being held before they could be performed as an exhibit for the kagaiha:

The wrestlers, always elements of different tribes, presented themselves in twos, their body painted, partly with yellow-red anatto, and partly with black paint. They crouched, took a handful of soil from the ground, moved quickly one around the other, always crouched and with their arms hanging, they took each other's measure by sight, deeply spiteful, shouting,
Figure 1 - Summoning and exhibition of the kindotoko. In the background, the "owners of the egitsü" (with their backs to the camera) and the "common wrestlers" of the host team. will be fabricated, on a regional level their bodies and performances are exhibited, mainly through wrestling (Costa, 2020). 
threatening "huuhá! Húuhá!" [...] Suddenly, the two would rise, each one looking to grab their partner's head. Despite all of their efforts, none succeeded in grabbing and lowering the other. In the end they embraced, very content, receiving friendly pats on their shoulders. There was no proper fight; the main aim seems to have been to display agility and to avoid one of the two from having their heads suddenly grabbed, and brought to the ground. Spectators were profoundly silent; except for the giggles of some more critical bystanders (Steinen, 1940, p. 142. Emphasis added).

Despite being an early description, it synthetically narrates the development of the combat: the wrestlers coming onto the scene shouting onomatopoeias, the struggle to grab an opponent's hands and neck, the short duration of the match and high incidence of draws. Although it is unclear at what event the match took place, it corroborates the communion between wrestler and fans and how emotions are transferred from the individual to the collective.

Among the Trumai, a people who speak a linguistic isolate and which live at the margins of the Upper Xingu regional system (Monod-Becquelin, 2001), Murphy \& Quain (1955) describe situations in which the matches occurred alongside warfare activity, or, even more tellingly, raids aimed at capturing women, destroying enemy villages, and killing enemy peoples were momentarily suspended so that wrestling matches could take place ${ }^{13}$. This points to differences between peoples who wrestled and those who did not, at a time when ambiguity characterized inter-ethnic relations, emphasizing, at the same time, the connections between competitors and fans:

Wrestling matches were especially frequent during intertribal visits and ceremonials. These occasions aroused keen interest, and competitive spirits ran high, but the onlookers made it a point of etiquette to show no partisanship, and the contestants made every effort to conceal latent intertribal hostility. (1955, p. 91. Emphasis added).

In a similar vein, Schaden traces the proximities and differences between the speakers of Arawak, Carib, Tupi and Gê languages in the region, relying on the "acculturation" and exchanges that took place, noting that wrestling was less common among Gê-speakers, particularly the Suyá. This would ultimately keep them outside of the ritual complex that would be consolidated some time later, due to their constant movement, mainly because of warfare with their neighbours. Stressing, again, the ambiguity of inter-ethnic relations and the danger of ritual events, Schaden writes:

What seems to matter is the fact that the wrestlers do not face off individually, as mere members of their tribes; during the match, the competitor acts, as it were, as the "official" delegate of his group, in such a way that spectators abstain from any manifestations for or against those who are
13 Stories are still told of a past in which people were invited to rituals and were decimated upon arrival at a foreign village. These acts are always perpetrated by "others", however. At present, fears regarding these feasts are due to sorcery. 
facing each other. It is obvious that this absence of "cheering" has the function of avoiding that the tension that exists between the groups relaxes into violence. (Schaden, 1965, p. 81. Emphasis added).

In these short passages, we can see some of the transformations that wrestling has undergone. As these pioneering authors claim, the absence of any performance from the spectators was crucial in order to avoid any rush or animosity. At a time when warfare and rituals were concomitant, varying in relation to and with whom they were carried out, wrestling was a peaceful if tenuous way of dealing with alterity. One did not fight against those whom one wrestled; women were not captured from them but exchanged with them; their villages were not destroyed, but rather food was offered to them - despite the ambiguities that remained in these relationships.

Suspicions of the other were (and perhaps continue to be) a danger that had to be avoided, whence the reluctance of spectators to celebrate the victories of their wrestlers. In contrast, one of the most notable expressions of contemporary wrestling matches is this transferal of emotions between wrestlers and fans, which can even result in fights and threats of cutting ties (Costa 2013, p. 121). If the current relational moment is reified in ritual pacification, this does not mean that animosities and tensions regarding the other are absent (cf. Schaden ibid, note 15, p. 83).

In the post-demarcation period, wrestling consolidates inter-ethnic relations and comes to shape the system, as noted by researchers studying different peoples and working in different theoretical perspectives. Warfare, in contrast, declines. Ritual comes to be the culmination and lingua franca of this multi-ethnic and multi-linguistic regional complex. Authors such as Agostinho (1974b) refer to wrestling as the "escape valve" for the tensions produced both in factional disputes within villages, which are particularly charged among the Kamayurá, and in the inter-tribal level where they emerge as a mechanism for "cooling off tensions".

Menezes Bastos $(1989,2001)$ links wrestling in the egitsü to the dart-throwing competitions of the jawari, a ritual that originally came from Tupi-speaking peoples, to discuss the "complementarity" of these rituals in the establishment of "Xinguanization", ceremonial relations as the stamp of the mutual "taming" of peoples who increasingly abandoned warfare for competitions. In contrast to other parts of Amazonia, in the Upper Xingu warfare is no longer a moment in social reproduction. Indeed, it became unproductive. It does not confer names, songs, dreams, but rather acquires a negative value and a defensive character: "In the Xingu, violence was ritualized and expressed as sportive fights, an obligatory event in intertribal rituals" (Fausto, 2007, p. 28. Emphasis added).

According to Viveiros de Castro, wrestling is at the centre of corporality as a focal symbolic idiom, and the whole process of fabricating bodies, particularly in pubescent seclusion, was decisive for the ritual matches: "The focus of inter-village ceremonies is the corporal fights between men - and the fabrication of the body of the fighter is one of the dominant concerns of this culture" (Viveiros de Castro, 1977, p. 185). Carneiro (1993, p. 427) furthermore proposes that rituals are 
an opportunity to reunite and interact with members of other villages, reaffirming social, ceremonial, sportive, and economic bonds, thereby promoting social solidarity.

We thus move from processes of "acculturation", which occurred in contacts between people speaking languages from different linguistic families, to the consolidation of ritual as a mark of relations with alterity, and the transformation of the enemy into an adversary, expressed in sportive events held between people who consider each other to be "human". All of this during a time in which a "people" and a "village" were generically interchangeable; in other words, despite changes concerning which people would ultimately become a part of this regional complex, each village was taken to be a "people". So, while the lessening of contacts between the "originary" Xinguan Arawak/Carib peoples and the Trumai and Suyá means that the latter no longer take part in ritual events, the Tupi-speaking "recent Xinguans" (so-called), such as the Kamayurá and the Aweti, come to be incorporated into this ritual universe $\mathrm{e}^{14}$.

For present purposes, this ethnographic base, which points to the diversity of the constitution of this regional complex and its transformations into peaceful relations, can be divided into two complementary tendencies: strategic alliances and the composition of wrestling teams, and the subsequent relation between wrestlers and spectators. The political feud between chiefs is actualized in the organization of ritual, both in the formation of teams as well as, eventually, in the exclusion of certain chiefs from certain rituals.

This variety and its characteristic instability set the scene for the articulation of two important themes: the multifaceted inter-ethnic ceremonial universe, as manifest in the creation of teams and their strategic alliances and historic oppositions, and the importance of the gaze in the consolidation of the relation between wrestling and cheering.

\section{Looking/Playing/Cheering: nginiko and mediation of wrestlers and fans}

One of the basic issues in studies of games, of the ludic character of certain human manifestations through space and time, is how emotions are transferred, how success and failure at an individual level are shifted to the collective level, and the connections between the practice of playing and the performance of cheering. This relation between the individual level of playing and the feeling of belonging mobilized by a cheering collectivity is shot through by the determining function of the gaze. This is how Toledo (2019) establishes the relation between these three domains, looking/playing/cheering, and their associations through the emotions promoted by sportive practices. In this model, looking is playing, or, rather, a tension is established in the dialectic between watched game and playful look through the relationships between the practitioners and their fans.

To elaborate this model, based on the ethnography of the development of so-called sportive practices, a series of authors were consulted regarding an understanding of this universe in dichotomic terms: ludic/competitive; equilibri-
14 This is so despite the fact that the Aweti did not participate in any of the eight events I observed. When I asked why they were absent, I was told that "the Aweti have no champion", which stresses that wrestling is the reason for inviting peoples to take part in rituals in honour of dead chiefs. 
um/tension; play/game. The opposition between the ostensibly disinterested ludic dimension, which is historically determined by a pre-modern cultural order, and the competitive aspects of sportive practices, a phenomenon constitutive of bourgeois societies, have been widely debated in the literature by authors such as Huizinga (1993[1938]), Caillois (1988[1950]), and Elias (1992), according to dominant perspectives at the time in which they wrote and considering their specific analytical aims:

The result of this, in what pertain to the model, is that all playing is a watched game. To look is to make things coexistent, to make them into objects or objectives. This model of relations treats players and onlookers as belated occurrences of the senses and metaphorizations of the experiences of playing and looking (Toledo, 2019, p. 44. Emphasis added).

With this, I now return to ceremonial wrestling and the pacification of relations, which has been amply attested both in native discourse and in the analyses of researchers. This relation becomes more evident as it expresses the indissociability of looking/playing/cheering. It is with this aim that I will use the model, by focusing on the relation between wrestling (playing), the makeup of the spectators (cheering) and the figure of the nginiko, the "onlookers" (looking). I will show, ethnographically, the connection between these acts during the match and its variations, the production and transferal of emotions emerging from the results of the combats.

The nginiko are not referees, they do not determine the results of matches, nor do they influence their proceedings, but rather they promote connections between those who play and those who cheer, between the wrestlers who are wrestling at the moment and their various supporters. Due to the organizational complexity of the rituals, the kinship relations between the chiefs and the honoured dead are substantially altered at each event, thereby ratifying situational rivalries and alliances. The same supporter who cheered the victory of a competitor in one match can cheer against him a few days later when the configuration of the teams and their supporters has changed. This is how the relation between playing and cheering, mediated by looking, reveals itself as most fundamental to the development of the combats and inter-ethnic relations.

In what pertains to results, these are not measured by sequential and cumulative counting, but instead by differential performances - of the wrestlers, who should toss their opponents with strength and acumen, but also of the fans who should yell increasingly louder with each new victory. This is where the "onlooker" emerges as important: the distance between the wrestlers and the supporters makes it difficult to discern the different forms of victory, by tossing or by touching the back of an opponent's leg.

It is the onlookers who call the victory of a competitor whenever this has not come by in an incontestable manner. The nginiko mediate between the competitors' enactment, as they display refined techniques to defeat their opponents, 
and the performance of the supporters, who should shout loudly to suppress the possibility that the result be contested whenever victory is not attained absolutely. This is why this crucial position for the development of the combats cannot just be occupied by anyone. It is a place occupied by former champions, masters of this martial art, familiar with techniques and tactics. In brief, these mediators have the "domesticated gaze" of a body produced for wrestling.

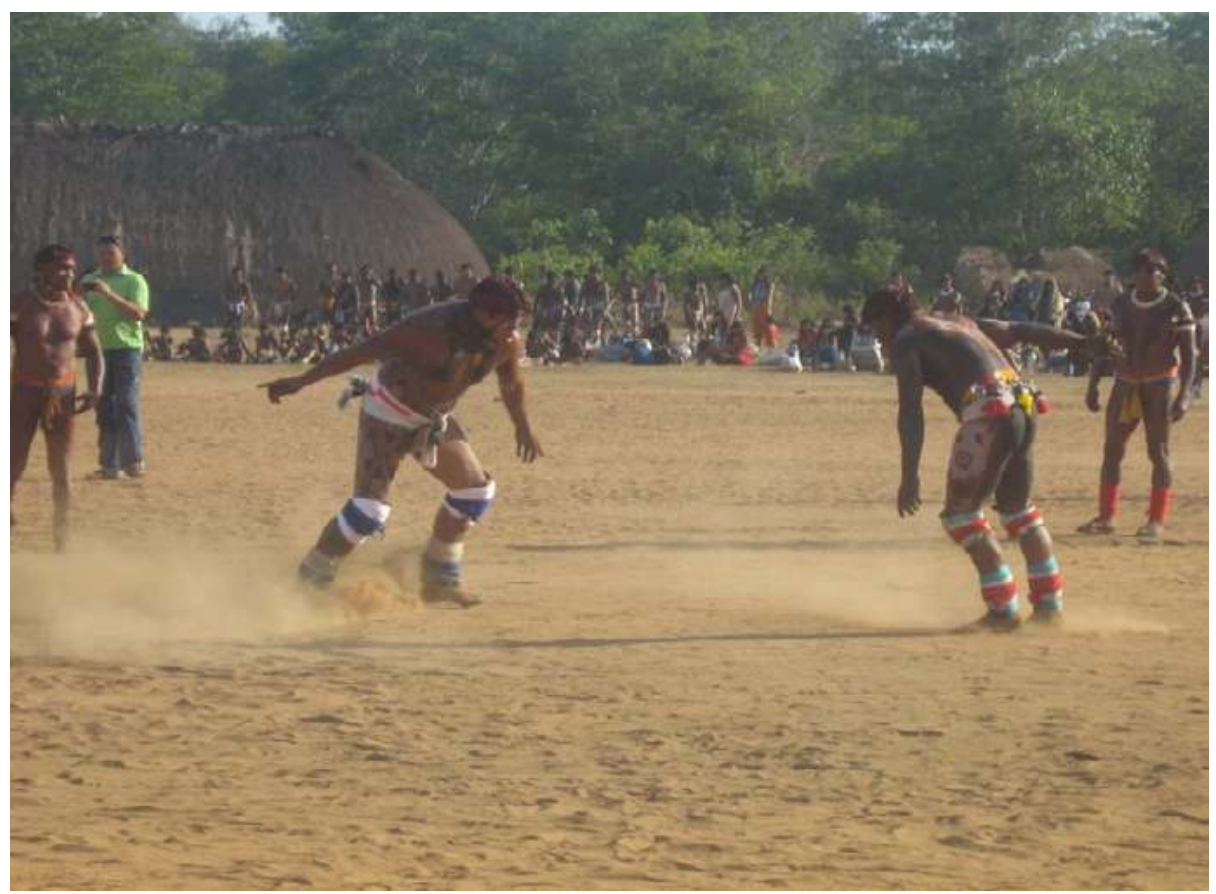

Not by chance, it is common for both groups of supporters to yell out different results. There are three possible outcomes: victory, defeat and a draw. A draw is by far the most common result, occurring in some $70 \%$ of matches. While these are the possible outcomes of a match, for supporters there are only two: the excited and heated shouts of victory, and the half-hearted and drowsy shouts of the draw. A defeat is suffered in silence.

So, seeing victory, particularly a victory that leaves some margin for doubt, requires extrapolating the senses if it is to be celebrated effusively with shouting. This type of celebration, in turn, is possible in the context of pacification and greater control of the emotions. Often, different groups of supporters shout out contradictory results for the same match: an onlooker calls the victory of his wrestler, and he is then followed by his group of supporters, while the other onlooker also calls on his own supporters to sing for the victory of their competitor. This purported confusion can occur when one calls victory and the other calls a draw. If results leave a margin of doubt, the dispute in play is transferred/transformed to a dispute in cheering, mediated by the look of the onlooker.

The quest for glory that is a staple of all ludic activity brings wrestlers and fans into association, collectivities which are formed differently at each new ritual event. Indeed, looking/playing/cheering can be an analytical key for a question that is often raised: how are successes (and failures) on the individual level transferred to the collective level? In a context in which warfare activity was present,
Figure 2 - Start of a match, under the careful gaze of the nginiko. 
emotions needed to be contained, and effusive behaviour and animosities had to be avoided. However, now that the practice is disputed ritually, commemorations have intensified and added dynamism to inter-ethnic oppositions.

Rivals in an egitsü can cheer for their former adversary in the subsequent event, but the way they cheer will be the same: shouting for a victory, or muffled murmur for a draw. Ethnographically, to be sure, alliances are limited in light of matrimonial possibilities that emphasise certain associations while restricting others ${ }^{15}$. My point here is to show that, despite this variety, those who are part of the same group of supporters in a specific event will cheer for their wrestler, even if that wrestler is not from one's village or people. This symbiosis between wrestler and fans promotes immediate identifications, marked by ritual space/ time, which breach village, ethnic and linguistic limits, establishing a strategic momentary alliance.

To form great teams, which do not lose when they are hosts, is one of the greatest challenges for the owners of the egitsï. So, the alliance between groups related to the dead person allows distinct peoples to form a single wrestling team. This team will have for its hotuko only the best wrestlers of each of the peoples who make up the alliance, not as an end in itself, but as a means for obtaining the best results. Independently of the people and the village, the fans will sing his victory ${ }^{16}$.

As well as demonstrating ethnographically the link between playing and cheering, Upper Xinguan wrestling presents us with a mediating figure whose purpose is, precisely, to look; that is, the relationship between sportive practice and cheering practice is mediated by the practice of looking. Looking/Playing/ Cheering make up a continuum which varies according to the relations between owners, allies, and guests. The production and transferal of emotions is a facet of all of the participants, whether they be wrestlers with their technical skills, onlookers who mediate between playing and cheering, fans whose conflicting performances, particularly in matches with unclear results, are the targets of expectations and disputes.

\section{Final Thoughts}

This article has sought to associate two analytical models that converge when seen from the vantage point of a universe which involves disputes through wrestling matches. The first concerns the social construction of chieftaincy through practices of "looking”, of "being seen", "becoming known", and through mortuary rituals. It is in the duplication of the innate and the acquired that the great chiefs are formed, through the continuity of substantive and corporal continuity, or lineage and genealogy, since, to be a chief, one must be the son of a chief. However, chiefs are also made through public performances (Guerreiro, 2012).

Since the ear-piercing rituals, young men are exhibited regionally to attest to the continuity of the chieftaincy. Having their ears pierced with the femur of a jaguar, sitting on the benches, being "guided by their wrists", being received in foreign villages, all of this is a part of the vast process of corporeal fabrication
15 Perhaps the most emblematic case is that of the Yawalapiti, who restructured themselves through strategic marriages with Kalapalo, Kuikuro and Kamayurá chiefs (Menezes Bastos 1989; Guerreiro 2012).

16 As an ethnographic example, I draw attention to the Kalapalo/Matipu alliance. Although the egistü took place in the Matipu village, only one local wrestler was part of the team of champions; the rest were Kalapalo. That is, even with alliances through kinship, strategies for the contests are the determining factor in the makeup of teams, which are chosen by the owner of the egitsü. In another example, Kalapalo/Yawalapiti together formed an unbeatable team. However, when they were opponents, their main wrestlers, the "first" of each one, performed one of the most exciting contemporary rivalries - one which had previously been played out by their fathers. Matches between them are moments of great expectation and enthusiasm from the fans - in some matches, even, both sets of fans celebrate the victory of their competitor. But when they were in the same team, the Kalapalo and Yawalapiti came together to celebrate their victories. 
and the formation of the person, the final aim of which is to make renown chiefs (tuhitinhü). To be a great wrestler, a champion who presents himself among the "firsts", who does not lose, is an apex of this construction of chiefs, the "biographical aspect" of the making of chiefs (Barcelos Neto, 2005). The egitsü is the moment when chiefs of the past are honoured by chiefs of the present, and in which they display future chiefs to their regional rivals.

Although all young men wrestle, only those who are in the lines of succession to the chieftaincy can actually become champions, whether because of their families, the processes required by seclusion, traditional teaching and ritual position. Not by chance, all of the great chiefs of the present are considered to have been great wrestlers in their day, and this is recognized regionally.

Furthermore, I have also considered the centrality of looking, the visibility of chiefs who present themselves for ritual combat, through another function of the gaze, namely, that which is established between playing and cheering. Dealing with the links between playing and cheering as mediated by looking, I have sought to consider a set of transformations that, in the end, re-dimensioned the inter-ethnic relations between the different peoples that live in the region. At first, when the instability of relations made warfare a constant threat, the relationship between spectators was basically inexistent. Spectators had to abstain from celebrating a victory or provoking rivals due, precisely, to the ambiguity inherent in wrestling matches between opponents who were potential enemies. However, the transformational processes known as the pax xinguana ultimately ratified a regional system in which, in some cases, many different people live in a single village, sharing a common ethnonym.

Gradually, some people dropped out of the network of invitations, supposedly for not having champion wrestlers. As the participants of regional rituals became consolidated, the performances of the fans became more active. This is visible in the transformations in cheering linked to the gaze of the nginiko. If in the past celebrations were contained, today they are elicited by this "onlooker", although, as with any sportive events, rivalries can flourish and fights can break out, despite the pax xinguana. In these events, the role of the chief in cooling animosities is fundamental.

In this way, the inter-ethnic relations that unfold ritually are observed in a new light, which reveals its dynamism, particularly given the current context of a growing number of villages associated with a single people and their makeup, as expressed in the idea of tetsualï. The power and prestige of chiefs are put to the test at each new event, with the formation of a good wrestling team being one of the factors that participants assess with greatest care. "Strategic alliances" are hence resumed, no longer for warfare incursions, but for ritual disputes with their characteristic variability. 


\section{References}

AGOSTINHO, Pedro. Mitos e outras narrativas Kamayura. Salvador: Editora da UFBA, 1974a.

AGOSTINHO, Pedro. Kwarip: mito e ritual no Alto Xingu. São Paulo: EPU/EDUSP, 1974b.

BARCELOS NETO, Aristóteles. Apapaatai: rituais de máscaras no Alto Xingu. Tese (Doutorado em Antropologia) - Universidade de São Paulo, São Paulo, 2005.

BARCELOS NETO, Aristóteles. De divinações xamânicas e acusações de feitiçaria: imagens wauja da agência letal. Mana - Estudos de Antropologia Social, n. 12, p. 285-313, 2006.

BASSO, Ellen. The Kalapalo Indians of Central Brazil. New York: Holt, Rinehart \& Winston, 1973.

BASSO, Ellen. A história na mitologia: uma experiência dos Avoengos Calapalos com Europeus. In: COELHO, V. (Org.). Karl von den Steinen: um século de antropologia no Xingu. São Paulo: EDUSP, 1993. p. 313-345.

BASSO, Ellen. The Last Cannibals: A South American Oral History. Austin: University of Texas Press, 1995.

CAILLOIS, Roger. Jogo e Sagrado. In: CAILLOIS, R. O Homem e o Sagrado. Lisboa: Edições 70, 1988 [1950].

CARNEIRO, Robert. Quarup: A Festa dos Mortos no Alto Xingu. In: COELHO, V. (Org.). Karl von den Steinen: um século de antropologia no Xingu. São Paulo: EDUSP, 1993. p. 405-429.

CLASTRES, Pierre. Arqueologia da violência: a guerra nas sociedades primitivas. In: CLASTRES, P.; GAUCHET, M.; ADLER, A.; LIZOT, P. (Orgs.). Guerra, religião, poder. Lisboa: Edições 70, 1980. p. 11-47.

COELHO DE SOUZA, Marcela. Virando gente: notas a uma história Aweti. In: B. FRANCHETTO, B.; HECKENBERGER, M. (Orgs.). Os Povos do Alto Xingu: história e cultura. Rio de Janeiro: Editora da UFRJ, 2001. p. 358-400.

COHN, Clarice; SZTUTMAN, Renato. O visível e o invisível na guerra ameríndia. Sexta Feira, n. 7, p. A43-A54, 2003.

COSTA, Carlos. Kindene hekugu. Uma etnografia da luta e dos lutadores no Alto Xingu. Tese (Doutorado em Antropologia) - Universidade Federal de São Carlos, São Carlos, 2013.

COSTA, Carlos. Política da reclusão: chefia e fabricação de corpos no Alto Xingu. R@U, v. 12, n. 1, p. 145-172, 2020. Disponível em: https://doi.org/10.52426/rau.v12i1.335. Acesso em: 20 abr. 2021.

ELIAS, Norbert.; DUNNING, Erik. A busca da excitação. Lisboa: Diffel, 1992.

FAUSTO, Carlos. Da Inimizade: forma e simbolismo da guerra indígena. In: NOVAES, A. (Org.). A Outra Margem do Ocidente. São Paulo: Cia. das Letras, 1999. p. 251-282.

FAUSTO, Carlos. Entre o Passado e o Presente: mil anos de história indígena no Alto Xingu. Revista de Estudos e Pesquisas, n. 2, p. 9-52, 2007.

FAUSTO, Carlos. Donos demais: maestria e domínio na Amazônia. Mana - Estudos de Antropologia Social. v. 14, n. 2, 2008. p. 329-366.

FAUSTO, Carlos. Chefe Jaguar, Chefe Árvore: afinidade, ancestralidade e memória no 
Carlos Eduardo Costa

Alto Xingu. Mana - Estudos de Antropologia Social. v. 23, n. 3, p. 653-676, 2017.

FRANCHETTO, Bruna; HECKENBERGER, Michael (Orgs.). Os Povos do Alto Xingu: história e cultura. Rio de Janeiro: EDUFRJ, 2001.

GALVÃO, Eduardo. O uso do propulsor entre as tribos do Alto Xingu. In: Encontros de Sociedades: índios e brancos no Brasil. Rio de Janeiro: Paz e Terra, 1979. p. 39-56.

GREGOR, Thomas. Uneasy Peace: Intertribal Relations in Brazil's Upper Xingu. In: HAAS, J. (Org.). The Anthropology of War. Cambridge: Cambridge University Press, 1990. p. 105-124.

GUERREIRO, Antonio. Ancestrais e suas sombras: Uma etnografia da chefia kalapalo e seu ritual mortuário. Tese (Doutorado em Antropologia) - Universidade de Brasília, Brasília, 2012.

GUERREIRO, Antonio. Quarup: transformações do ritual e da política no alto Xingu. Mana - Estudos de Antropologia Social, n. 21, p. 377-406, 2015.

GUERREIRO, Antonio. Do que é feita uma sociedade regional? Lugares, donos e nomes no Alto Xingu. Ilha - Revista de Antropologia, n. 18, p. 23-55, 2016.

HUGH-JONES, Stephen; GUERREIRO, Antonio; ANDRELLO, Geraldo. Space-time Transformations in the Upper Xingu and Upper Rio Negro. Sociologia \& Antropologia, n. 5, p. 699-723, 2015.

HUIZINGA, Joan. Homo Ludens. São Paulo: Perspectiva, 1993.

LEA, Vanessa Rosemary: Parque Indígena do Xingu: Laudo antropológico. Campinas: Universidade Estadual de Campinas, 1997.

LEITE LOPES, José. Esporte, emoção e conflito social. Mana - Estudos de Antropologia Social, n. 1, p. 141-166, 1995.

MEHINAKU, Mutua. Tetsualü: pluralismo de línguas e pessoas no Alto Xingu. Dissertação (Mestrado em Antropologia Social) - Museu Nacional, Universidade Federal do Rio de Janeiro, Rio de Janeiro, 2010.

MELLO, Maria. lamurikuma: música, mito e ritual entre os Wauja do Alto Xingu. Tese (Doutorado em Antropologia Social) - Universidade Federal de Santa Catarina, Florianópolis, 2005.

MENEZES BASTOS, Rafael. O "payemeramaraka" kamayurá: uma contribuição à etnografia do xamanismo no Alto Xingu. Revista de Antropologia, n. 27-28, p. 139-177, 2018.

MENEZES BASTOS, Rafael. Exegeses yawalapití e kamayurá da criação do Parque Indígena do Xingu e a invenção da saga dos irmãos Villas Boas. Revista de Antropologia, n. 30/31/32, p. 391-426, 1989.

MENEZES BASTOS, Rafael. Indagação sobre os kamayurá, o alto-xingu e outros nomes e coisas: uma etnologia da sociedade Xinguara. Anuário Antropológico, n. 94, p. 227269, 1995.

MENEZES BASTOS, Rafael. Ritual, História e Política no Alto Xingu: Observações a partir dos Kamayurá e do Estudo da Festa da Jaguatirica (Jawari). In: FRANCHETTO, B.; HECKENBERGER, M. (Orgs.). Os Povos do Alto Xingu: história e cultura. Rio de Janeiro: Editora da UFRJ, 2001. p. 335-357.

MENEZES, Maria. Parque Indígena do Xingu: a construção de um território estatal. Campinas: Editora da Unicamp; Imprensa Oficial, 2000.

MONOD-BECQUELIN, Aurore. Histórias trumais. In: FRANCHETTO, B.; HECKENBERGER, 
M. (Orgs.). Os Povos do Alto Xingu: história e cultura. Rio de Janeiro: Editora da UFRJ, 2001. p. 401-443.

MURPHY, Robert F.; QUAIN, Buell. The Trumai Indians. Monographs of the American Ethnological Society, XXIV, New York, v. xii, n. 108, p. in-8, 1955.

NOVO, Marina; GUERREIRO, Antonio. Exchange, Friendship and Regional Relations in the Upper Xingu. Vibrant: Virtual Brazilian Anthropology, n. 17, p. e17354. Epub August 07, 2020. Disponível em: https://doi.org/10.1590/1809-43412020v17a354. Acesso em: 10 abr. 2021.

PERRONE-MOISÉS, Beatriz. Festa e Guerra. Tese (Livre-docência) - Universidade de São Paulo, São Paulo, 2016.

SCHADEN, E. Três Exemplos. Revista de Antropologia, n. 13, p. 65-152, 1965.

SEEGER, Anthony; DAMATTA, Roberto; VIVEIROS DE CASTRO, Eduardo. A Construção da pessoa nas sociedades indígenas brasileiras. Boletim do Museu Nacional, n. 32, p. 2-19. 1979.

STEINEN, Karl. Entre os Aborígines do Brasil Central. Revista do Arquivo Municipal, separata: XXXIV e LVIII, 1940.

TOLEDO, Luiz. Torcer: Perspectivas analíticas em Antropologia das práticas esportivas. Tese (Livre-docência) - Universidade Federal de São Carlos, São Carlos, 2019.

VANZOLINI, Marina. A flecha do ciúme: o parentesco e seu avesso segundo os Aweti do Alto Xingu. Tese de Doutorado, Rio de Janeiro: Museu Nacional, 2010.

VIANNA, Fernando. Boleiros do cerrado: Índios Xavantes e o futebol. São Paulo: Annablume; FAPESP; ISA, 2008.

VIVEIROS DE CASTRO, Eduardo. A fabricação do corpo na sociedade xinguana. Boletim do Museu Nacional, n. 32, p. 40-49, 1979.

VIVEIROS DE CASTRO, Eduardo. Indivíduo e Sociedade no Alto Xingu: os Yawalapíti. Dissertação (Mestrado em Antropologia Social) - Museu Nacional, Universidade Federal do Rio de Janeiro, Rio de Janeiro, 1977. 